$\mathrm{K}$

STUDIA Z PRAWA WYZNANIOWEGO

Tom $22-2019$

DOI: https://doi.org/10.31743/spw.5481

WŁODZIMIERZ BROŃSKI*

\title{
PRAWNOAUTORSKIE ASPEKTY KAZANIA
}

\section{Streszczenie}

Przedmiotem artykułu jest przedstawienie wybranych aspektów prawnoautorskiej ochrony kazania. Kazanie będąc formą posługi słowa Bożego, jest regulowane prawem kościelnym, ale równocześnie podlega prawu polskiemu. W związ$\mathrm{ku} \mathrm{z}$ tym przedstawiono najpierw obowiązujące $\mathrm{w}$ tym zakresie przepisy prawa wewnętrznego Kościoła Katolickiego i prawa państwowego - przede wszystkim ustawę o prawie autorskim i prawach pokrewnych z 4 lutego 1994 roku. Następnie stwierdzono, że kazanie jest utworem w rozumieniu prawa autorskiego i podlega ochronie, jeżeli wykazuje wszystkie trzy cechy konieczne do uzyskania tejże kwalifikacji: stanowi rezultat pracy człowieka (kaznodziei), jest działalnością twórczą o indywidualnym charakterze i jest uzewnętrznione w żywym przepowiadaniu konkretnego kaznodziei lub też w formie opublikowanego tekstu kazania. W ostatniej części na podstawie analiz prawnych i literatury z zakresu homiletyki zdiagnozowano podstawowe problemy współczesnego kaznodziejstwa i w związku z tym sformułowano wskazania dla praktyki przepowiadania wynikające $\mathrm{z}$ prawnej ochrony kazania jako utworu. Artykuł napisano z wykorzystaniem metody dogmatycznoprawnej i historycznoprawnej.

Slowa kluczowe: prawo autorskie; kazanie; duchowny; autor; utwór

$$
* * * * *
$$

* Ks. dr hab., Katedra Negocjacji i Mediacji, Wydział Prawa, Prawa Kanonicznego i Administracji, Katolicki Uniwersytet Lubelski Jana Pawła II, Al. Racławickie 14, 20-950 Lublin, e-mail: mediacja@kul.pl. ORCID 0000-0002-1303-6737. 


\section{WPROWADZENIE}

Wszyscy obywatele, zobowiązani są do respektowania regulacji prawnych w zakresie prawa autorskiego. Tym samym reżim prawa autorskiego musi być przestrzegany również $\mathrm{w}$ działalności religijnej Kościoła Katolickiego, w tym także podczas sprawowania kultu religijnego. Stąd w niniejszym opracowaniu po omówieniu zobowiązań Kościoła Katolickiego w zakresie ochrony praw autorskich zostaną omówione zagadnienia kazania jako przedmiotu prawa autorskiego, a także przedstawione wskazania dla kaznodziejów wynikające z ochrony prawnoutorskiej tej kategorii utworów ${ }^{1}$.

\section{KOŚCIÓŁ KATOLICKI A PRAWA AUTORSKIE}

Obowiązek respektowania w działalności kościelnej regulacji prawnoautorskich wynika zarówno z przepisów prawa świeckiego ${ }^{2}$, jak i z prawa wewnętrznego Kościoła Katolickiego. Art. $12 \S 1$ ustawy o gwarancjach wolności sumienia i wyznania ${ }^{3}$ stanowi, że „,duchowni oraz osoby zakonne kościołów i innych związków wyznaniowych, ustanowione według przepisów prawa wewnętrznego kościoła lub innego związku wyznaniowego, korzystają z praw i podlegają obowiązkom na równi z innymi obywatelami we wszystkich dziedzinach życia państwowego, politycznego, gospodarczego, społecznego i kulturalnego (...)”. Równocześnie zgodnie z § 3 ni-

1 Tekst niniejszego artykułu zapoczątkowuje szerzej zakrojone badania naukowe nad prawnoautorskimi aspektami kazania.

2 Istotny wpływ na interpretację przepisów prawa autorskiego ma Konstytucja Rzeczypospolitej Polskiej z 2 kwietnia 1997 roku (Dz. U. z 1997 r. Nr 78, poz. 483 z późn. zm.). Mowa w niej o: ochronie podmiotów praw wyłącznych w związku z gwarancjami konstytucyjnymi dotyczącymi własności i innych praw majątkowych (art. 64 § 1 i 2); dopuszczalnej eksploatacji cudzych utworów (znaczenie ma tutaj art. 54 odwołujący się do wolności wyrażania swoich poglądów oraz pozyskiwania i rozpowszechniania informacji); wolności twórczości artystycznej, badań naukowych oraz ogłaszania ich wyników, wolności nauczania, wolności korzystania z dóbr kultury (art. 73). Markiewicz 2018, 24.

3 Ustawa z dnia 17 maja 1989 r. o gwarancjach wolności sumienia i wyznania, tekst jedn. Dz. U. z 2017 r., poz. 1153. 
niejszej normy prawnej, uprawnienia i obowiązki osób duchownych w myśl prawa państwowego określają odrębne ustawy. W Polsce zagadnienie praw autorskich reguluje przede wszystkim ustawa o prawie autorskim i prawach pokrewnych z 4 lutego $1994 \mathrm{roku}^{4}$. Przedmiotem prawa autorskiego jest „każdy przejaw działalności twórczej o indywidualnym charakterze, ustalony w jakiejkolwiek postaci, niezależnie od wartości, przeznaczenia i sposobu wyrażenia (utwór)" (art. $1 \S 1$ pr.aut.) ${ }^{5}$. Ratio legis prawa au-

4 Tekst jedn. Dz. U. z 2019 r., poz. 1231. Dalej: pr.aut. Ustawa ta jest podstawowym aktem normatywnym regulującym aktualnie ochronę autorską w Polsce. Ponadto należy uwzględnić także wydane na jej podstawie akty wykonawcze, ustawę o ochronie baz danych z dnia 27 lipca 2001 roku (Dz. U. z 2001 r. Nr 128, poz. 1402 z późn. zm.), ustawę o zbiorowym zarządzaniu prawami autorskimi i prawami pokrewnymi z dnia 15 czerwca 2018 roku (Dz. U. z 2018 r., poz. 1293). Znaczenie odgrywają także ustawy inne niż prawo autorskie: Kodeks cywilny z dnia 23 kwietnia 1964 roku (tekst jedn. Dz. U. z 2019 r., poz. 1145), Prawo własności przemysłowej z dnia 30 czerwca 2000 r. (tekst jedn. Dz. U. z 2017 r., poz. 776), ustawa z 16 kwietnia 1993 r. o zwalczaniu nieuczciwej konkurencji (tekst jedn. Dz. U. z 2019 r., poz. 1010) oraz umowy międzynarodowe dotyczące praw autorskich i ochrony praw człowieka. Dla ustalenia koniecznego zakresu ochrony prawnoautorskiej znaczenie ma także prawo Unii Europejskiej. Zob. Markiewicz 2018, 23-29.

5 Definicja utworu zawarta $\mathrm{w}$ art. $1 \S 1$ pr.aut. nawiązuje do określenia tego pojęcia w ustawie z dnia 29 marca 1926 roku o prawie autorskim (Dz. U. z 1935 r. Nr 36, poz. 260). Art. 1 tej ustawy stanowił, że ,,przedmiotem prawa autorskiego jest od chwili ustalenia w jakiej bądź postaci (słowem żywym, pismem, drukiem, rysunkiem, barwą, bryłą, dźwiękiem, mimiką, rytmiką) każdy przejaw działalności duchowej, noszący cechę osobistej twórczości”. Podobnie jak obecnie, przepis ten zawierał przykładowy katalog utworów chronionych prawem autorskim. Katalog ten miał kazuistyczny charakter. Obecna ustawa skupia się bardziej na poszczególnych kategoriach utworów, które są wyodrębnione według różnych kryteriów, przy czym poszczególne kategorie utworów krzyżują się wzajemnie, a nawet zawierają. Okoliczność ta, jak zauważają J. Barta i R. Markiewicz, nie ma istotnego znaczenia, ponieważ prawo autorskie (z wyjątkiem programów komputerowych, dzieł audiowizualnych i utworów architektonicznych) nie różnicuje zasad ochrony utworu w zależności od jego kategorii. Dla pełnego obrazu należy jeszcze podkreślić, że ustawa o prawie autorskim z 10 lipca 1952 roku (Dz. U. Nr 34, poz. 234 z poźn. zm.) wprawdzie zawierała przykładowe wyliczenie dzieł będących przedmiotem prawa autorskiego, to jednak nie zawierała syntetycznego określenia utworu. W art. $1 \S 1$ stanowiła jedynie, że przedmiotem prawa autorskiego jest każdy utwór literacki, naukowy i artystyczny ustalony w jakiejkolwiek postaci. 
torskiego stanowi ochrona praw twórcy utworu ${ }^{6}$. Co do zasady ochronie podlegają prawa, które przysługują twórcy wobec utworu.

Obowiązek ochrony praw autorskich w Kościele Katolickim wynika również z Konwencji Berneńskiej z dnia 9 września 1886 roku. Akt paryski Konwencji Berneńskiej o ochronie dzieł literackich i artystycznych sporządzony w Paryżu w dniu 24 lipca 1971 roku został ratyfikowany zarówno poprzez Rzeczpospolitą Polską ${ }^{7}$, jak i przez Stolicę Apostolską ${ }^{8}$. W art. 2 Konwencji wyliczono utwory takie jak: książki, broszury i inne pisma, przemówienia, odczyty, kazania ${ }^{9}$, itp. Jako podstawowe przesłanki powstania praw autorskich prawodawca wylicza cechy osobistej twórczości oraz ustalenie utworu w jakiejkolwiek postaci. Polska i Stolica Apostolska są również stronami Powszechnej konwencji o prawie autorskim z dnia 6 września 1952 roku $^{10}$.

6 Ustawodawca używa terminu „twórca” w sposób niekonsekwentny. Od interpretacji każdego przepisu, w którym to określenie jest użyte, zależy, czy oznacza ono tylko autora, czyli osobę, która stworzyła utwór, czy też każdy podmiot (pierwotny lub pochodny) majątkowego prawa autorskiego. Twórca w znaczeniu autor to osoba, która stworzyła utwór (art. $1 \S 1$ pr.aut.). Status twórcy przysługuje wyłącznie osobie fizycznej, ponieważ tylko taka osoba może podejmować działalność twórczą, której przejawy stanowią utwór, jeżeli cechują się indywidualnym charakterem. Termin ten jest przyjęty w przepisach dotyczących autorskich dóbr osobistych i niezbywalnych praw majątkowych autora, w tym także spadkobierców autora. Termin „twórca” odnosi się natomiast do uprawnionego podmiotu autorskich praw majątkowych, gdy dany przepis ze względu na swoją treść dotyczy tego rodzaju praw (np. art. $1 \S 4$ pr.aut.). W tych sytuacjach poprawnym rozwiązaniem byłoby używanie terminu ,uprawniony” zamiast określenia „twórca”. Zob. Markiewicz 2018, 197; Nowicka 2013, 81.

7 Dz. U. z 1990 r. Nr 82, poz. 474.

8 Stolica Apostolska ratyfikowała Konwencję Berneńską w dniu 12 września 1935 roku w wersji redakcji rzymskiej z 1928 roku, a od 24 kwietnia 1975 roku jest stroną konwencji w wersji paryskiej.

9 Terminy ,kazanie”, „tekst kazania” będą używane zamiennie na określenie jednostki przepowiadania słowa Bożego.

10 Powszechna konwencja (copyright) o prawie autorskim zrewidowana w Paryżu dnia 24 lipca 1971 r. (Dz. U. z 1978 r. Nr 8, poz. 28, zał.). Polska ratyfikowała tę Konwencję 9 grudnia 1976 roku. Najnowsza jej wersja jest z 2 października 1979 roku. Stolica Apostolska ratyfikowała Konwencję i jest jej stroną od 6 maja 1980 roku. 
W Kodeksie Prawa Kanonicznego z 1983 roku nie ma regulacji odnoszących się wprost do praw autorskich ${ }^{11}$. Jedyną normą prawną stanowiącą obowiązek ochrony praw autorskich w powszechnym prawodawstwie Kościoła Katolickiego jest kan. 666 Kodeksu Kanonów Kościołów Wschodnich z 1990 roku $^{12}$, który przyznał prawo do własności intelektualnej autorowi, stanowiąc: „dzieło intelektualne autora jest pod ochroną prawną, zarówno gdy tworzy jego uprawnienia osobiste, jak też jako źródło praw dziedzicznych" ( $§ 1)$. Natomiast $\S 3$ tego przepisu odsyła do stosowania w tym zakresie prawa partykularnego Kościoła i ustawodawstwa świeckiego. W literaturze wyrażany jest pogląd, iż wobec luki w systemie prawnym Kościoła łacińskiego w kwestii ochrony praw autorskich, kan. $666 \mathrm{KKKW}$ posiada znaczenie normatywne także w Kościele łacińskim, ponieważ zasady interpretacji prawa odsyłają do całego ustawodawstwa Kościoła ${ }^{13}$. Znajduje on swoje uzasadnienie w zasadzie ogólnej KPK: „Jeśli w określonej sprawie brak wyraźnej ustawy, powszechnej lub partykularnej, albo prawa zwyczajowego, sprawa - z wyjątkiem karnej - winna być rozstrzygnięta $z$ uwzględnieniem ustaw wydanych w podobnych sprawach, ogólnych zasad prawnych z zachowaniem słuszności kanonicznej, jurysprudencji, praktyki Kurii Rzymskiej oraz powszechnej i stałej opinii uczonych" (kan. 19). Zatem z mocy wskazanych wyżej przepisów ustawa z dnia 4 lutego 1994 roku o prawie autorskim i prawach pokrewnych wraz z aktami wykonawczymi może być stosowana przed sądami kościelnymi $\mathrm{w}$ Polsce, $\mathrm{w}$ zakresie, $\mathrm{w}$ jakim nie jest ona sprzeczna $\mathrm{z}$ normami prawa kanonicznego ${ }^{14}$.

W kontekście analizowanego zagadnienia istotne znaczenie ma również odwołanie się ustawodawcy kościelnego wprost do ustaw cywilnych, m.in. w zakresie norm dotyczących umów i zobowiązań (KPK kan. 1290). Warunkiem jest jednak ich niesprzeczność z prawem Bożym i systemem

11 Codex Iuris Canonici auctoritate Joannis Pauli PP. II promulgatus. Acta Apostolicae Sedis 75 (1983), s. 1-317. Dalej: KPK.

12 Codex Canonicum Ecclesiarum Orientalium auctoritate Joannis Pauli PP. II promulgatus. Acta Apostolicae Sedis 82 (1990), s. 1033-1363. Dalej: KKKW.

13 Adamowicz, Kawa 2000, 52.

14 Tylec 2016, 94. 
prawa kościelnego ${ }^{15}$. Znalazło to dodatkowe potwierdzenie w art. 23 Konkordatu z 1993 roku $^{16}$.

Ochrona praw autorskich w Kościele Katolickim to nie tylko problem prawny, ale również problem natury moralnej. Przywłaszczenie sobie autorstwa czyjegoś utworu jest kradzieżą. Według św. Tomasza z Akwinu własność stanowi bowiem instytucję prawa ogólnoludzkiego (ius gentium) niemal powszechnie uznanego i przyjętego przez narody, którego normy są wyprowadzane z podstawowych zasad prawa naturalnego (prima principia $)^{17}$. Immanentnymi cechami własności są: jej naturalność polegająca na przynależności do ius gentium oraz wynikaniu z zasad prawa naturalnego, a także rozumność i pożyteczność ${ }^{18}$.

Wprawdzie w Katechizmie Kościoła Katolickiego brak bezpośrednich odniesień do prawa autorskiego, ale jest mowa o kradzieży. „Wszelkiego rodzaju przywłaszczenia i zatrzymywanie niesłuszne do-

15 W odniesieniu do zobowiązań międzynarodowych kan. 3 KPK i kan. 4 KKKW ustanawiają zasadę pierwszeństwa prawa międzynarodowego przed prawem wewnętrznym Kościoła. Tym samym nie zmieniają umów zawartych przez Stolicę Apostolską z krajami. Ponadto w prawie partykularnym Kościoła w Polsce nie znajdujemy również norm szczegółowych dotyczących praw autorskich. Jedynymi wyjątkami są: pismo Nuncjusza Apostolskiego (N. 5299/98) z dnia 5 września 1998 roku oraz Komunikat Sekretariatu Konferencji Episkopatu Polski z dnia 5 listopada 1998 roku (Akta KEP, nr 2, s. 91). Komunikat ten stwierdza, że dysponentem autorskich praw majątkowych związanych z dokumentami papieskimi i Stolicy Apostolskiej jest Konferencja Episkopatu Polski, a publikacja tychże tekstów wymaga każdorazowego pisemnego zezwolenia Sekretariatu Konferencji Episkopatu Polski. Adamowicz, Kawa 2000, 54.

16 Konkordat między Stolicą Apostolską i Rzeczpospolitą Polską podpisany w Warszawie dnia 28 lipca 1993 roku (Dz. U. z 1998 r. Nr 51, poz. 318). Art. 23 Konkordatu stanowi, że kościelne osoby prawne mogą zgodnie z przepisami prawa polskiego nie tylko nabywać dobra materialne, tj. mienie nieruchome i ruchome, ale także niematerialne dobra kościelne, wymienione w tym przepisie explicite jako prawa majątkowe. Dokonywanie przez struktury Kościoła wszystkich działań w sferze majątkowej zgodnie z regułami państwowego prawa cywilnego harmonizuje z tendencją do kanonizowania tego prawa, czyli do uznawania jego przepisów za obowiązujące w kościelnym prawie majątkowym [Góralski, Pieńdyk 2000, 128], co w odniesieniu do regulacji prawnych, mających za zadanie ochronę autorskich praw majątkowych, oznacza przede wszystkim konieczność zapewnienia zgodności zawieranych umów z ustawą o prawie autorskim i prawach pokrewnych. Skwierczyński 2017, 43-44.

17 Thomas de Aquino, Ia-II ae, q. 94, a. 5 ad 3.

18 Zob. Włodarczyk 2010, 621-635. 
bra drugiego człowieka, nawet jeśli nie sprzeciwia się przepisom prawa cywilnego, sprzeciwia się siódmemu przykazaniu (...) Świadome wyrządzanie szkody własności prywatnej lub publicznej jest sprzeczne z prawem moralnym i domaga się odszkodowania" (nr 2409) ${ }^{19}$. Siódme przykazanie uwydatnia prawo człowieka do posiadania rzeczy jako dóbr. Chodzi w nim nade wszystko o osoby, a o rzeczy ze względu na osoby $^{20}$. Związek autora ze swoim utworem jest jak najbardziej osobisty. Przywłaszczenie czyjegoś utworu odnosi się do człowieka i jest ingerencją w jego sferę intymną ${ }^{21}$.

Papieska Rada ds. Środków Społecznego Przekazu, w związku z rozpowszechnianiem się Internetu, w dokumencie „Etyka w Internecie” podnosi m.in. kwestie etyczne w takich sprawach jak prawa autorskie i prawo do własności intelektualnej. Stwierdza, że ,[w]iele trudnych kwestii związanych z Internetem wymaga konsensusu międzynarodowego: na przykład (...) w jaki sposób chronić prawa autorskie i prawa do własności intelektualnej, nie ograniczając dostępu do materiałów będących własnością publiczną, i [w] jaki sposób zdefiniować samą «własność publiczną»; w jaki sposób powoływać i utrzymywać szerokie internetowe bazy informacji, tak by były swobodnie dostępne dla wszystkich" (nr 17)22.

Podsumowując, należy podkreślić, że w Kościele Katolickim twórca kazania powinien zachowywać zarówno normy moralne, jak i przestrzegać przepisy prawa wewnętrznego Kościoła Katolickiego i prawa świeckiego, w tym obowiązującej ustawy o prawie autorskim i prawach pokrewnych. Kazanie jako utwór podlega ochronie z mocy tej ustawy (art. $1 \S 4$ ).

19 Jan Paweł II. 2015. Katechizm Kościoła Katolickiego. Poznań: Wydawnictwo Pallottinum.

20 Jan Paweł II. Homilia wygłoszona w dniu 5 czerwca 1991 r. w Białymstoku https:// opoka.org.pl/biblioteka/W/WP/jan_pawel_ii/homilie/20bialystok_05061991.html [dostęp: 12.07.2019].

21 Naganowski 2008, 73.

22 Papieska Rada ds. Środków Społecznego Przekazu, Etyka w Internecie (Watykan, 22 lutego 2002 r.), https://opoka.org.pl/biblioteka/W/WR/rady_pontyfikalne/r_komunik_ spol/internet_etyka_22022002.html\#m1 [dostęp: 12.07.2019]. 
KAZANIE JAKO PRZEDMIOT PRAWA AUTORSKIEGO

Kazanie rozumiane jako jednostka przepowiadania słowa Bożego może być uznana za przedmiot prawa autorskiego, jeżeli jako rezultat pracy człowieka (kaznodziei) będzie posiadać pozostałe dwie cechy konieczne do uzyskania kwalifikacji ,utworu” w rozumieniu art. $1 \S 1$ pr.aut., to jest: będzie działalnością twórczą o indywidualnym charakterze oraz zostanie uzewnętrznione w żywym przepowiadaniu konkretnego kaznodziei lub też w formie opublikowanego tekstu kazania. Kazanie jako utwór stanowi dobro niematerialne, które może być przyporządkowane określonej osobie kaznodziei i stanowi przedmiot stosunków prawnych. Jest określoną konstrukcją ludzkich myśli i wyobrażeń, a jego intelektualny charakter zaznacza się w dwóch płaszczyznach: powstaje w świadomości kaznodziei i stanowi wynik jego ludzkiej kreacji ${ }^{23}$.

Jeden z najważniejszych problemów stanowi tutaj określenie „twórczość o indywidualnym charakterze" ${ }^{24}$. Kryterium ta przesądza o dwóch kwestiach. Z jednej strony o tym, czy określony wynik pracy intelektualnej jest utworem w rozumieniu prawa autorskiego, a z drugiej, które składniki utworu są chronione przez prawo. Monopol kaznodziei wobec poszczególnych składników kazania jest podyktowany właśnie poprzez tę autorskoprawną przesłankę twórczości. Składniki kazania nieposiadające tej cechy mogą być bez ograniczeń eksploatowane przez osoby trzecie, również w czasie trwania ochrony autorskiej ${ }^{25}$.

Kryterium „twórczości o indywidualnym charakterze” jest niedookreślonym pojęciem prawa autorskiego ${ }^{26}$. Wywołuje ciągłe spory w doktrynie

23 Zob. Niewęgłowski 2013, 21.

24 W prawie UE kryterium to nosi nazwę ,własna intelektualna twórczość”. Zob. Wyrok TS z dnia 16 lipca 2009 r. w sprawie C-5/08, Infopaq International A/S przeciwko Danske Dagblades Forening.

25 Zob. Markiewicz, 2018, 39-40.

26 Duże trudności sprawia oznaczenie koniecznego ,granicznego” poziomu indywidualności, który pozwala uznać dany rezultat pracy intelektualnej za utwór w rozumieniu art. $1 \S 1$ pr.aut. W tym kontekście ważny jest wywód zawarty w orzeczeniu Sądu Apelacyjnego w Krakowie z dnia 29 października 1997 roku (I ACa 477/97). Sąd stwierdza, że ,nie da się generalnie oznaczyć minimum indywidualności, które stanowiłoby wartość progową dla uzyskania ochrony w prawie autorskim i pozwalałoby w sposób dostatecznie bezpieczny 
i jest niekonsekwentnie interpretowane w orzecznictwie sądowym. Jednak niektóre ustalenia związane z tym kryterium nie budzą wątpliwości. Po pierwsze, utwór musi stanowić przejaw „działalności twórczej”, czyli aktywności o charakterze kreacyjnym. W doktrynie i orzecznictwie podkreśla się, że wprawdzie przepis ustawy wymaga, aby utwór stanowił rezultat działalności o charakterze twórczym, to ważny jest nie sam proces twórczy, a bezwarunkowo jego rezultat ${ }^{27}$. Utwór musi być subiektywnie nowy ${ }^{28}$, a więc z perspektywy twórcy choćby w minimalnym stopniu odróżniający się od innych rezultatów takiego samego działania ${ }^{29}$. Nie może być przejęty z innego dzieła, czyli to, co zostało stworzone, nie było uprzednio znane w takiej samej postaci. Stopień nowości nie ma znaczenia, ale żeby nowość mogła zaznaczyć się w utworze, autor musi mieć co najmniej w pewnym stopniu wpływ na jego kształt ${ }^{30}$.

Równocześnie konieczna jest druga właściwość takiego utworu nazywana: cechą indywidualności, własną intelektualną twórczością, osobistym charakterem dzieła, oryginalnością, piętnem osobistym ${ }^{31}$. Autor powinien nadać tworzonemu dziełu właściwości wynikające z jego niepowtarzalnej osobowości.

Indywidualny charakter utworu to właściwość łącząca utwór z określoną osobą w sposób uzasadniający węzeł autorstwa ${ }^{32}$. Oznacza to, że

rozróżnić wytwory intelektualnie zdatne i niezdatne do ochrony. W każdym przypadku budzącym wątpliwość, tj. wtedy, gdy indywidualność badanego wytworu intelektualnego nie jest intuicyjnie oczywista, zachodzi konieczność odwołania się do ocen wartościujących. W ocenach tych należy kierować się dyrektywą nakazującą uwzględnić zarówno aksjologiczne uzasadnienie norm prawa autorskiego, jak i właściwości wytworów intelektualnych poddanych ocenom wartościującym”. Lex nr 533708. Zob. także Jaworski 2009, 321.

27 Zob. I ACa 477/97, Lex nr 533708. Barta 2005, 66-68.

28 „(...) o danej działalności możemy powiedzieć, że jest twórcza, gdy wytwór tej działalności jest nowy co najmniej subiektywnie (nowy dla twórcy). Twórczość z kolei ma indywidualny charakter, gdy rezultat tej twórczości jest nowy obiektywnie (dla odbiorców wyróżnia się spośród istniejącego zasobu utworów)”. Niewęgłowski 2013, 10-11.

29 Zdaniem Sądu Najwyższego wystarczy, aby dzieło ,wykazywało pewne elementy twórcze, choćby minimalne". Orzeczenie Sądu Najwyższego z dnia 31 marca 1953 r. (II C 834/52), niepubl.

30 Niewęgłowski 2013, 9.

31 Markiewicz 2013, 40.

32 Niewęgłowski 2013, 9. 
utwór sam przez się musi wyróżniać się od innych takich samych przejawów działalności twórczej, w sposób który będzie świadczył o jego oryginalności, swoistości, jak też o wszystkich właściwościach sprawiających, że w większym lub mniejszym stopniu jest on niepowtarzalny i nie posiada swego wiernego odpowiednika w przeszłości ${ }^{33}$. Przy czym, co podkreśla się w doktrynie, samo stwierdzenie cech twórczych w konkretnym wytworze, nie może prowadzić do wniosku, że ma on indywidualny charakter ${ }^{34}$.

Proces twórczy nad kazaniem jest ze swej natury kreowaniem kazania - niepowtarzalnej jednostki przepowiadania słowa Bożego w słowie ludzkim. Nie sprowadza się do naśladownictwa, ale jest przejawem działalności twórczej osoby kaznodziei - aktem kreatywnym ${ }^{35}$. Z teologicznego punktu widzenia kreatywność na gruncie kaznodziejstwa jest konieczna. Kreatywną nazywamy twórczość zmierzającą do wytworzenia dzieła noszącego znamię nowości. Za kreatywną w teorii homiletycznej nazywamy taką myśl, która w określonych okolicznościach jest całkowicie nowa bądź zawiera jakieś nowe elementy i pomaga ludziom w rozwiązaniu ich życiowych problemów. Kreatywność odnosi się do całej Bosko-ludzkiej rzeczywistości kazania, a nie tylko do zewnętrznej jego formy ${ }^{36}$. Kazanie bierze swój początek w umyśle twórcy, jest wytworem jego pracy, charakteryzuje się nowością rezultatu, oryginalnością - posiada indywidualny charakter.

Aby można było zakwalifikować kazanie jako utwór, konieczne jest jeszcze jego ustalenie w jakiejkolwiek postaci (art. $1 \S 1$ pr.aut.), czyli jego zakomunikowanie osobom innym niż twórca. Uzewnętrznienie jest warunkiem powstania dzieła, które $\mathrm{z}$ tą chwilą zaczyna podlegać ochronie. Nie może bowiem być objęty ochroną autorską wytwór, który istnieje jedynie w pamięci twórcy. Pojęcia „ustalenie” nie należy też utożsamiać z utrwaleniem, czyli zapisaniem utworu na jakimkolwiek nośniku ${ }^{37}$.

Kazanie realizuje się ostatecznie w akcie jego wygłoszenia. Homileci zajmujący się pracą twórczą nad kazaniem w oparciu o model psychologii twórczości wskazują na komunikację kazania jako ostatni etap tego proce-

33 Tamże.

34 Krystyna Szczepanowska-Kozłowska. Glosa do wyroku SN z dnia 27 lutego 2009 r. (V CSK 337/08), OSP z 2010 r. Nr 3, poz. 33.

35 Zob. Rothermundt 1984, 133-142.

36 Bohren 1971, 76.

37 Jaworski 2009, 317. 
$\mathrm{su}^{38}$. Zadaniem kaznodziei jest ukształtowanie kazania, opanowanie jego treści i wygłoszenie zgodnie z przyjętymi zasadami. Kazanie z natury swej jest aktem mowy żywej. Kaznodzieja głosi je całą swoją osobą. Znajduje to wyraz zarówno w języku werbalnym, jakim się posługuje, jak i w zachowaniach niewerbalnych. Język kazania musi być mową żywą i różnić się od języka pisanego. W praktyce kazanie przechodzi jednak poprzez fazę języka pisanego. W teorii homiletycznej odróżnia się wygłoszenie kazania od tekstu kazania ${ }^{39}$. Rozróżnienie to nie ma jednak znaczenia dla prawa polskiego ${ }^{40}$. Ustalone w jakiejkolwiek postaci kazanie (wygłoszone, napisane) to „utwór” w rozumieniu ustawy o prawie autorskim i prawach pokrewnych, i podlega ochronie.

\section{WSKAZANIA DLA KAZNODZIEJÓW WYNIKAJĄCE Z PRAWNOAUTORSKIEJ OCHRONY KAZANIA}

Po pierwsze, zgodnie z art. $8 \S 1$ i 2 pr.aut. kaznodzieja, który stworzył kazanie i je rozpowszechnił poprzez jego wygłoszenie lub opublikowanie, np. w formie pisemnej, jest ,twórcą” w rozumieniu ustawy o prawie autorskim i prawach pokrewnych. Przysługują mu takie same uprawnienia jak innym twórcom - autorskie prawa osobiste (art. 16 pr.aut.) i autorskie prawa majątkowe (art. 17 pr.aut.). Autorskie prawa osobiste są związane $\mathrm{z}$ twórcą w sposób trwały. Istotą tych praw jest ich niezbywalny charakter. Nie podlegają zrzeczeniu się lub zbyciu. Są też bezterminowe, czyli nieograniczone w czasie (art. 16 pr.aut.). Chronią więź twórcy z utworem ze skutecznością erga omnes przed wszelkimi bezprawnymi działaniami ze strony osób trzecich. Naruszenie autorskich praw osobistych stanowi również naruszenie dóbr osobistych twórcy będących częścią dóbr osobistych powszechnego prawa cywilnego. Art. 23 kodeksu cywilnego posługuje się na ich określenie pojęciem „twórczość naukowa, artystyczna” i stwierdza,

38 Zob. Twardy 1998, 225-304.

39 Zob. Bartohlomäus 1974, 136-139.

40 Kazanie jako utwór wyrażony słowem, zgodnie z art. $1 \S 2$ pkt 1 pr.aut., jest „W szczególności” przedmiotem prawa autorskiego. Co więcej, jest przedmiotem prawa autorskiego, chociażby miało postać nieukończoną - np. wygłaszanie kazania zostało przerwane (art. $1 \S 3$ pr.aut.). 
że ,pozostają pod ochroną prawa cywilnego niezależnie od ochrony przewidzianej w innych przepisach" ${ }^{\prime 1}$.

Twórca kazania, jako podmiot praw autorskich, posiada również prawa majątkowe do stworzonego utworu, czyli prawo do korzystania z utworu i rozporządzania nim na wszystkich polach eksploatacji oraz do wynagrodzenia za korzystanie z utworu (art. 17 pr.aut.). Są to prawa podmiotowe. Mają charakter zbywalny i można nimi dysponować w drodze czynności prawnych, a także podlegają dziedziczeniu (art. $41 \S 1$ pr.aut.). Prawa te wygasają, tj. ich czas trwania jest ograniczony (art. 36 pr. aut.). Po upływie terminów w stosunku do określonych utworów przechodzą one do domeny publicznej i są chronione wyłącznie w zakresie autorskich praw osobistych. Wówczas można korzystać z takich utworów bez potrzeby zawierania umów licencyjnych i rozliczania wynagrodzeń, pamiętając o nieograniczonych w czasie prawach osobistych do danego utworu.

Kaznodzieja, mając zagwarantowaną prawem ochronę utworów własnego autorstwa, nie powinien naruszać tychże praw w praktyce kaznodziejskiej. Tym bardziej, że kazanie z założenia jest wypowiedzią osobistą kapłana o indywidualnym charakterze. Fakt, że od strony teologicznej kaznodzieja jest drugorzędnym podmiotem przepowiadania i że proces wygłoszenia jest zasadniczo wspólnym działaniem wszystkich uczestników (Bóg, kaznodzieja, słuchacze), nie ma znaczenia dla obowiązującego prawa świeckiego ${ }^{42}$.

Po drugie, analiza współczesnej literatury homiletycznej wskazuje, że jednym z najbardziej niepokojących zjawisk we współczesnej praktyce kaznodziejskiej jest brak umiejętności odpowiedniego korzystania z cudzych tekstów. Zadaniem kaznodziei jest tłumaczenie ludzkiego życia w świetle tekstów świętych, budzenie i umacnianie wiary oraz prowadzenie słucha-

41 Sąd Najwyższy w wyroku z dnia 5 stycznia 2001 roku (V CKN 499/00) dopuszcza zarówno kumulatywne, jak i alternatywne dochodzenia ochrony autorskich praw osobistych - tak na podstawie ustawy o prawie autorskim i prawach pokrewnych, jak i na podstawie kodeksu cywilnego - a wyboru dokonuje twórca. Natomiast Sąd Apelacyjny w Krakowie w wyroku z dnia 7 lutego 1995 roku (I ACr 697/94) stwierdził, że przepisy ustawy o prawie autorskim i prawach pokrewnych są przepisami szczególnymi wobec kodeksu cywilnego. Dlatego do ochrony twórczości winno się stosować ustawę o prawie autorskim i prawach pokrewnych. Zob. Panowicz-Lipska 2016, 130-131.

42 Siwek 1994, 182-183. 
czy kazań do zbawienia. Spełnianie takiej posługi domaga się twórczego kaznodziei, który całą swoją osobowość angażuje w to, co głosi, komu głosi i jak głosi. Jego osobowość, a także kwalifikacje i dyspozycje mają bowiem znaczenie dla treści, formy i pośrednio także skuteczności zbawczej kazania. Tak więc bez odpowiedniego udziału czynnika osobowego, bez pożądanych przymiotów i uzdolnień oraz pomysłowości i pracowitości kaznodziei, nigdy nie będzie dobrego kazania ${ }^{43}$. Korzystanie w procesie twórczym z gotowych ,pomocy homiletycznych” jest jak najbardziej pożądane i dopuszczalne prawnie, ale nie można z nich korzystać w sposób dowolny nie tylko ze względów etycznych i dobrych obyczajów, ale i przestrzegania obowiązujących przepisów prawa autorskiego.

Korzystając z wiedzy zgromadzonej w literaturze i kazaniach innych autorów, należy w kazaniu przywołać źródło pozyskanej wiedzy. W utworach wyrażonych słowem wyróżniamy zazwyczaj warstwę wytworzoną samodzielnie przez autora publikacji, warstwę autorską przejętą przez tego autora od innych twórców i warstwę informacyjną, stanowiącą tzw. domenę publiczną. Wykorzystywanie w kazaniu warstwy autorskiej innych twórców domaga się respektowania ich praw autorskich ${ }^{44}$. Zgodnie z prawem polskim kaznodzieja korzystając z cudzych utworów w tzw. „granicach dozwolonego użytku”, czyli takiego, który nie narusza normalnego korzystania z utworu lub godzi w słuszne interesy twórcy (art. 35 pr.aut.), powinien wymienić z imienia i nazwiska twórcę oraz źródło pochodzenia utworu ${ }^{45}$.

Wydaje się, że odpowiednią formą ,dozwolonego użytku” jest posłużenie się prawem cytatu. Instytucja ta pozwala bowiem wyważyć interesy autorów i użytkowników w celu upowszechnienia i rozwoju wiedzy oraz swobody wypowiedzi. Cytować można tylko utwór rozpowszechniony, czyli taki, który został już w jakikolwiek sposób udostępniony publicznie za zgodą autora (art. $6 \S 1$ pkt 3 pr.aut.). Zawsze też należy zadbać o zachowanie proporcji pomiędzy inkorporowanym utworem (np. tekstem) a całością powstającego dzieła. Wykorzystywany w ramach prawa cytatu utwór

43 Tamże, 183.

44 Naganowski 2008, 75.

45 Wówczas twórcy przytaczanego fragmentu nie przysługuje prawo do wynagrodzenia, chyba że ustawa stanowi inaczej (art. 34 pr.aut.). 
powinien być przytoczony w niezmienionej wersji, w przypadku utworu wyrażonego słowami (np. literackiego) w wersji dosłownej, w literalnym brzmieniu $^{46}$. Zachowaniem niedopuszczalnym jest natomiast czytanie całości lub fragmentu cudzego tekstu kazania in extenso i podawanie siebie w sposób bezpośredni lub domniemany dla czytelników lub słuchaczy za autora kazania (art. $16 \S 1$ i 2 pr.aut.). Nawet wtedy, kiedy kaznodzieja czyta kazanie, które oddane jest do swobodnego użytku, np. w zbiorze kazań służących jako pomoce homiletyczne, powinien poinformować słuchaczy, kto jest autorem tego kazania ${ }^{47}$.

Po trzecie, podstawowym tworzywem kazania jest Pismo Święte, Tradycja, liturgia, nauczanie Urzędu Nauczycielskiego Kościoła. Źródła te nie są przedmiotem prawa autorskiego. Zatem nie podlegają ochronie. Jednak już tłumaczenie Pisma św. może korzystać z ochrony prownoautorskiej jako autorskie prawa zależne w rozumieniu art. $2 \S 1$ pr.aut. Opracowanie bowiem cudzego utworu, w szczególności tłumaczenie, jest przedmiotem prawa autorskiego bez uszczerbku dla prawa do utworu pierwotnego ${ }^{48}$, jeżeli wykazuje „własne cechy twórcze”. Musi być przejawem działalności twórczej o indywidualnym charakterze. Jeżeli tych warunków nie spełnia, to nie może powstać prawo autorskie do tegoż opracowania ${ }^{49}$. Kaznodzieja zawsze jednak powinien wskazywać, tak jak w przypadku czerpania z literatury czy gotowych kazań, źródło pochodzenia przejętych cytatów, parafraz, przykładów, itp. i oznaczać ich autorstwo. W kazaniu głoszonym można to uczynić skrótowo, natomiast w publikowanym obowiązuje pełny opis bibliograficzny ${ }^{50}$. W przypadkach naruszenia praw autorskich kazno-

46 Zob. Stanisławska-Kloc 2009, 160-184.

47 „Wprawdzie zbiory kazań są wydawane właśnie w celu wykorzystania przez innych duchownych, to jednak z samego celu takiego wydawnictwa nie można domniemywać zupełnie swobodnego użycia zamieszczonych w książkach treści. Byłoby wskazane, aby tego typu publikacje zawierały, dla pewności prawnej, jasno określoną zgodę (licencję) zawierającą zakres użycia materiałów w nich umieszczonych”. Kroczek 2016, 71. Pośród innych naruszeń prawa autorskiego przez kaznodziejów należy wymienić jeszcze naruszenie prawa do integralności utworu oraz nierzetelność w wykorzystaniu utworu. Tenże, 71-72.

48 Konwencja Berneńska stanowi: „Bez uszczerbku dla praw autora dzieła oryginalnego, na równi z utworami oryginalnymi podlegają ochronie tłumaczenia, adaptacje, układy muzyczne i inne opracowania dzieła literackiego lub artystycznego" (art. 2 § 3).

49 Barta, Markiewicz, Matlak 2013, 57.

50 Naganowski 2008, 74. 
dzieja zgodnie z art. 115 i 116 pr.aut. podlega grzywnie, karze ograniczenia wolności lub pozbawienia wolności.

Reasumując, należy podkreślić, że kazanie - tak jak każda wypowiedź publiczna - podlega ocenie. Treść kazania powinna być zawsze rzetelna, zgodna z prawdą i zasadami współżycia społecznego. Kaznodzieje wygłaszając lub publikując kazania, powinni realizować naukę Kościoła, a także respektować przepisy prawa Kościoła Katolickiego i prawa świeckiego obwiązującego w tym zakresie.

\section{BIBLIOGRAFIA}

Adamowicz, Leszek, Mirosław Kawa. 2000. „Zobowiązania Kościoła katolickiego w zakresie ochrony praw autorskich". W: Przestanie chrześcijańskie a mass media, red. Adam Kaczor, 51-55. Lublin: Wydawnictwo KUL.

Barta, Janusz (i in.). 2005. Prawo autorskie i prawa pokrewne. Komentarz. Kraków: Zakamycze.

Barta, Janusz, Ryszard Markiewicz, Andrzej Matlak. 2013. „Podstawowe założenia regulacji”. W: System prawa prywatnego. T. 13. Prawo autorskie, red. Janusz Barta, 56-57. Warszawa: Wydawnictwo C.H. Beck.

Bartohlomäus, Wolfgang. 1974. Kleine Predigtlehre. Zürich: Verlag Benziger.

Bohren, Rudolf. 1971. Kleine Predigtlehre. München: Gütersloher Verlagshaus.

Góralski, Wojciech, Andrzej Piendyk. 2000. Zasada niezależności i autonomii państwa i Kościoła w konkordacie polskim z 1993 roku. Warszawa: Wydawnictwo UKSW.

Jaworski, Lech. 2009. „Utwór jako przedmiot prawa autorskiego”. Monitor Prawniczy 6: 316-325.

Kroczek, Piotr. 2016. „Kaznodziejstwo w optyce prawa cywilnego”, Ruch Biblijny i Liturgiczny 1: 65-82.

Markiewicz, Ryszard. 2018. Ilustrowane prawo autorskie. Warszawa: Wolters Kluwer.

Naganowski, Tomasz. 2008. „Cudze myśli i słowa w czyichś ustach”. W: Ściqgać czy nie ściagać? red. Maciej Kubiak, Wiesław Przyczyna, 67-80. Poznań: Drukarnia i Księgarnia Świętego Wojciecha.

Niewęgłowski, Adrian. 2013. „Wprowadzenie. Pojęcie utworu”. W: System prawa prywatnego. T. 13. Prawo autorskie, red. Janusz Barta, 9-31. Warszawa: Wydawnictwo C.H. Beck. 
Nowicka, Aurelia. 2013. „Podmiot prawa autorskiego”. W: System prawa prywatnego. T. 13. Prawo autorskie, red. Janusz Barta, 79-128. Warszawa: Wydawnictwo Beck.

Panowicz-Lipska, Janina. 2016. „Art. 23. Ochrona dóbr osobistych”. W: Kodeks cywilny. T. 1. Komentarz art. 1-449'11, red. Maciej Gutowski, 108-131. Warszawa: Wydawnictwo C.H. Beck.

Rothermundt, Jürg. 1984. Der Heilge Geist und die Rhetrorik. Theologische Grundlinien einer Empirischen Homiletik. Gütersloh: Gütersloher Verlagshaus Gerd Mohn.

Siwek, Gerard. 1994. „Proces tworzenia kazania”. W: Fenomen kazania, red. Wiesław Przyczyna, 177-213. Kraków: Poligrafia Towarzystwa Salezjańskiego.

Skwierczyński, Michał. 2017. „Kościelna osoba prawna jako licencjobiorca autorskich praw majątkowych". Kościót i Prawo 6/1: 43-54.

Stanisławska-Kloc, Sybilla. 2009. „Zasady wykorzystywania cudzych utworów: prawo autorskie i dobre obyczaje (etyka cytatu)". Diametros 19: 160-184.

Twardy, Jan. 1998. Koncepcja pracy twórczej nad kazaniem. Rzeszów: Poligrafia Wyższego Seminarium Duchownego.

Tylec, Grzegorz. 2016. „Prawo autorskie w działalności religijnej”. Studia z Prawa Wyznaniowego 19: 89-105.

Włodarczyk, Wojciech. 2010. „Własność intelektualna «według» św. Tomasza”. W: Wspótzależność dyscyplin badawczych w sferze administracji publicznej, red. Stanisław Wrzosek, Michał Domagała, Jan Izdebski, Tadeusz Stanisławski, 621-635. Warszawa: Wydawnictwo C.H. Beck.

\section{COPYRIGHT ASPECTS OF THE SERMON}

\section{Summary}

The article aims to present selected aspects of copyright protection of the sermon. A sermon, being a form of the ministry of God's word, is regulated by ecclesiastical law, but at the same time it is subject to Polish law. In view of this, the relevant provisions of the internal law of the Catholic Church as well as provisions of state law are introduced first, including especially the Act on Copyright and Related Rights of 4 February 1994. Next, it is argued that a sermon is a work under copyright law and it is protected if it exhibits all three qualities necessary to obtain this qualification: it is the result of a person's (preacher's) work, it is the product of creative activity of individual nature and it is externalized in the preaching of a particular preacher or in the form of a published text of the sermon. In the last part, the 
basic problems of modern preaching are identified on the basis of legal analyses and homiletic literature, followed by the guidelines for the practice of preaching resulting from the legal protection of the sermon. The article was written using the legal-dogmatic and legal-historical methods.

Key words: copyright law; sermon; preacher; author; work

Ttumaczenie wtasne autora 
